\title{
MAPPING OF ACCESS MODE CHOICE PROBABILITY BASED ON MULTINOMIAL LOGIT MODEL TO GET THE COMPETITION DESCRIPTION OF AIRPORT ACCESS MODES
}

\author{
WIRYANTA ${ }^{1}$, Ria Asih Aryani SOEMITRO ${ }^{1}$, Ervina AHYUDANARI ${ }^{\text {* }}$
}

DOI: $10.21163 / G T \_2019.142 .14$

\begin{abstract}
:
Airport mode choice is an essential facilities requirement for air travelers. The various purpose of the travelers from a vast area of origin needs to be accommodated in order to guarantee the seamless movement of the travelers. This paper proposes a model to provide an alternative of access mode choice for Juanda International Airport (JIA). The model is based on the mapping of air traveler characteristics from 38 Districts in East Java. This paper considered travelers pattern of JIA that was analyzed using a multi-nominal logit model. The obtained model is useful in developing a map for identifying the districts that can be facilitated by public transport. The results also provide variables effect in the mode selection process.
\end{abstract}

Key-words: Access mode, Mode choice, Mode choice probability.

\section{INTRODUCTION}

Quality of access land transport to or from the airport is greatly determined by the choice of its transportation mode. This mode choice is influenced by socioeconomic and demographic features, trip characteristics, available modal options, and road geographies (Pasha \& Hickman, 2016). Quality of access road is also influenced by the development of a city. Quantitatively, it can be stated that the bigger city in which there is an airport will lead to more number of access trip to or from the airport. JIA masterplan state that JIA was designed to serve ultimately 75 million per year.

This large number of passengers will cause high traffic access to JIA. Handling of access traffic must be adjusted to the results of in-depth research so that effective policies can be produced. The policy of regulating transportation access always leads to the use of high occupancy modes such as buses or trains. Therefore, it is important to examine the behavior of the choice of access mode in JIA with the consideration that the choice of modal behavior is unique which differs from one region to another or from one airport to another. The diversity of modal choice behavior is the result of the diversity of characteristics of airport users. Based on literature studies, many researchers have examined the choice of airport access modes. The purpose of research can be classified into two, namely identifying variables that influence the mode selection and making mathematical models of modal choices. Methodologically, the study of access mode choice can be distinguished based on the variables used, the type of model used for analysis and model segmentation. There are many variables that influence access mode choice in an airport. Each airport has unique variables, meaning that it differs from one airport to another. But there are 6 (six) variables that are most often used by researchers in constructing mode choice models at various airports in the world, as in Table 1.

\footnotetext{
${ }^{1}$ Department of Civil Engineering, Faculty of Civil, Environmental and Geo Engineering, Sepuluh NopemberInstitute of Technology, Surabaya,wiryanta@ugm.ac.id, ria@ce.its.ac.id, ervina@ce.its.ac.id ( ${ }^{*}$ Corresponding author)
} 
The most popular variables that influence airport access mode choice

Table 1.

\begin{tabular}{|l|l|l|}
\hline No. & \multicolumn{1}{|c|}{ Variables } & \multicolumn{1}{c|}{ Reseachers } \\
\hline 1 & Travel time & $\begin{array}{l}\text { Harvey (1986), Furuichi \& Koppelman (1994), Psaraki \& Abacoumcin } \\
(2002), \text { Gupta et al (2008), Jou et al (2011), Tam et al (2011), Alhussein } \\
\text { (2011), Keumi and Murakami (2012), Tsamboulas et al (2012), } \\
\text { Mamdoohi et al (2012), Choo et al (2013), Chang (2013), Akar (2013), } \\
\text { Roh (2013), Bao et al (2015), Lee Kyu et al (2016), Gokasar \& Gunay } \\
(2017)\end{array}$ \\
\hline 2 & Travel cost & $\begin{array}{l}\text { Harvey (1986), Furuichi \& Koppelman (1994), Psaraki \& Abacoumcin } \\
\text { (2002), Gupta et al (2008), Jou et al (2011), Tam et al (2011), } \\
\text { Tsamboulas (2012), Bao et al (2015), Gokasar \& Gunay (2017) }\end{array}$ \\
\hline 3 & Trip purpose & $\begin{array}{l}\text { Harvey (1986), Psaraki \& Abacoumcin (2002), Mamdoohi et al (2012), } \\
\text { Choo et al (2013), Chang (2013), Akar (2013), Roh (2013), Bao et al } \\
\text { (2015), Arbues et al (2016) }\end{array}$ \\
\hline 4 & $\begin{array}{l}\text { Household } \\
\text { income }\end{array}$ & $\begin{array}{l}\text { Harvey (1986), Gupta et al (2008), Alhussein (2011), Keumi and } \\
\text { Murakami (2012), Mamdoohi et al (2012), Choo et al (2013), Akar } \\
\text { (2013) }\end{array}$ \\
\hline 5 & $\begin{array}{l}\text { Airport user's } \\
\text { age }\end{array}$ & $\begin{array}{l}\text { Chebli \& Mahmassani (2003), Gupta et al (2008), Jou et al (2011), Tam } \\
\text { et al (2011), Mamdoohi et al (2012), Choo et al (2013), Chang (2013), } \\
\text { Akar (2013), Roh (2013) }\end{array}$ \\
\hline 6 & Gender & $\begin{array}{l}\text { Chebli \& Mahmassani (2003), Gupta et al (2008), Mamdoohi et al } \\
\text { (2012), Chang (2013), Akar (2013), Roh (2013) }\end{array}$ \\
\hline
\end{tabular}

There are three models that are often used in formulating airport access mode selection, namely the multinomial logit (MNL) model, nested logit (NL) and the multinomial probit (MNP) model. Among the three models, the MNL model is the most commonly used. Because mathematically the easiest execution. The MNL model must fulfill the axiom of Independent of Irrelevant Alternatives (IIA), that is "if two alternatives have the opportunity to be chosen, the ratio of one opportunity to another opportunity is not affected by the existence of other alternatives in a set of choices". So in MNL, the Pj / Pi ratio is a constant that does not depend on other choices. This can be considered as an advantage of the model because it can control new problems quite well. But this behavior is considered as a deficiency that causes the model to be not good if there are alternatives that are correlated.

The existence of modal hierarchies in one group or the existence of correlated modal choices causes the IIA axiom conditions to be unfulfilled. So in such conditions, the MNL model cannot be used. For this reason, a Nested Logit (NL) selection model is needed. According to Kropko (2008), the advantage of MNP compared to MNL or NL is that MNP is not associated with the axioms of IIA. But MNP is mathematically more complicated in its solution. In general, if there are N choices, then solving MNP uses N-1 tuple integrals. The MNP model will become unstable when executing mathematical equations with quadruple integrals upwards. In that condition, the MNP model will always fail to estimate. Therefore, MNP is more efficient when there are fewer choices. If there are more alternative modal choices (more than four choices), the MNL model is more stable than the MNP model. This research uses the MNL model because it involves 6 (six) modal choices and there is no hierarchy in the selection. 
The purpose of creating a mode choice model is to determine the behavior of airport users in selecting access modes. Quantification of this model will produce a modal choice probability. This probability will become a benchmark of acceptance or rejection of the access mode being operated. The identification of this probability value is the same as the identification of the market share of access mode users. To obtain complete identification results, the researchers made modeling classifications based on market segmentation. There are two segmentations most often made by researchers namely business and non-business (pleasure) (Furuichi \& Koppelman, 1994; Keumi and Murakami, 2012; Mamdoohi et al, 2012; Choo et al, 2013; Lee Kyu et al, 2016). Other segmentations that are also often made by researchers are residents and non-residents (visitors), as did Harvey (1986), Psaraki \& Abacoumcin (2002), Gupta et al (2008), Tam et al (2011). Of the many researchers in modeling the access mode, a segmentation based on the area of origin of the passengers in an airport catchment area has not been discussed. This might be caused by development of the city. For the city that growing not following certain pattern, the transportation facilities will be difficult to be provided. This segmentation is important in order to know the spatial distribution of demand in the airport catchment area. Information about the value of the probability of choice and spatial location of demand will be useful in designing routes for access modes that have certain routes such as buses or trains.

Based on the description above, a model based on the area of origin of the passenger has not been explored more. The origin of the air travelers will provide useful information in designing the type of access mode that is suitable for the certain airport. The origin of air traveler represents the accessibility index of the airport. The higher the index determines that the airport has high accessibility inland as well as air. Land accessibility means the air traveler has easiness in traveling to the airport, though they come from the far area from the airport. Air accessibility means that the airport provides a number of routes and has a high frequency of flight for each route.

This research focuses more on modeling the airport access mode based on the origin of passengers. This model will be a base of planning airport access mode in the populated area and distributed in wider coverage. Therefore, this research is expected to be an additional method in designing the airport access mode.

\section{METHODOLOGY}

\subsection{Factor Analysis}

Factor analysis is conducted in order to identify the effects of variables that have been studied previously. The analysis process consists of two processes namely data summarization and data reduction. Data summarization is the inter-variable correlation identification process; while data reduction is a new data set grouping so that there are simpler variable groups. This research involves 19 variables that are considered to have effects on access mode choice in Juanda International Airport. Factor analysis is performed on several groups of data that have been classified according to certain segmentation. In this analysis the data segmentation is based on the area of origin of air passengers. The factor analysis refers to the identification of any factors having effects on the airport access mode choice from passengers from various cities or regencies as the catchment area of Juanda International Airport. There are 29 regencies and 9 cities in East Java Province as the catchment area of Juanda International Airport. But, not all respondents taken from 
random survey represent 38 regency or city areas. Statistically, there are only 5 (five) areas meeting the data adequacy aspect, namely Surabaya, Sidoarjo, Malang, Jombang and Gresik.

\subsection{Mode Choice Model}

There are many studies related to the application of this airport access mode choice model. ACRP (2008) has launched some study results of this mode choice model application. The choice model structure is generic consisting of 3 types of models namely binomial logit/multinomial logit, nested logit and probit models. The binomial logit model is used to compete for two modes while multinomial logit is used to compete for more modes simultaneously. The nested logit is used if there is any mode grouping or mode hierarchy. The researchers have basic difference namely on the type of explanatory variables in the modeling. The explanatory variables for each airport are unique and reflect the behavior of mode users. It involves very various explanatory variables between one airport and others, also between one researcher and others. It is because of the different perception of interest level for each variable in each airport location. Then, the initial step to be done before building a model is exploring any considered important variables by airport users at Juanda International Airport, Surabaya. Contribution of each variable in the model will be the basis for making mode utility analysis and access mode choice probability in Juanda International Airport.

In the context of the choice model using two logistic function alternatives, it can be stated as follow:

$$
P(i)=\frac{1}{1+e^{-(U i-U j)}}
$$

In which $\mathrm{Ui}$ and $\mathrm{Uj}$ are the utility of $\mathrm{i}$-alternative and utility of $\mathrm{j}$ - alternative and $\mathrm{P}(\mathrm{i})$ is the probability of selecting $\mathrm{i}$ - alternative, then $\mathrm{P}(\mathrm{i})$ can also be stated in the following forms.

$$
P(i)=\frac{e^{U i}}{e^{U i}+e^{U j}}
$$

This form is known as Logit Model or precisely as Binomial Logit Model. If there are more than two choice alternatives, it can develop the following model:

$$
P(i)=\frac{e^{U i}}{\sum_{j \in J} e^{U j}}
$$

$\mathbf{J}$ is the number of alternatives. This function is called as Multinomial Logit (MNL). This function has been used broadly in mode choice modeling in the airport by involving two or more option alternatives. Initially, the mode choice model can be presented conventionally and easily in the form of S-curve. But in a further stage, the logit model function can be derived from utility maximum principles, in which decision-makers will select any alternatives with the highest utility. 


\subsection{Studied Variables}

Based on the literature review there are many variables that influence the choice of airport access modes. In this research, 19 variables will be examined which are expected to have a significant effect on the modal selection process at Juanda International Airport. The 19 variables are presented in Table 2.

Table 2.

Studied Variables

\begin{tabular}{|l|l|l|l|l|l|}
\hline No. & Symbol & \multicolumn{1}{|c|}{ Variables } & No. & Symbol & \multicolumn{1}{c|}{ Variables } \\
\hline 1 & Q1 & Income & 11 & Q11 & Frequency \\
\hline 2 & Q2 & Family number & 12 & Q12 & Party size of the traveler \\
\hline 3 & Q3 & Education & 13 & Q13 & Duration of waiting time \\
\hline 4 & Q4 & Purpose of trip & 14 & Q14 & Duration of walking time \\
\hline 5 & Q5 & Trip duration (travel time) & 15 & Q15 & Number of transfer \\
\hline 6 & Q6 & Number of baggage & 16 & Q16 & Security \\
\hline 7 & Q7 & Trip cost & 17 & Q17 & Comfort \\
\hline 8 & Q8 & Trip distance & 18 & Q18 & Baggage capacity \\
\hline 9 & Q9 & Punctuality & 19 & Q19 & Service satisfaction \\
\hline 10 & Q10 & Travel time reliability & & & \\
\hline
\end{tabular}

\section{STUDY AREA AND DATA}

\section{1. Data of passenger's reference}

In survey questionnaires, there are questions related to the social-economic data and preference data of respondents. Respondent preferences are respondent's response toward some variables that influence their access mode choice. In this survey, the respondents are asked to state their responses on the variables written on the questionnaires. The responses are stated into five category levels, namely, Strongly Agree (SA), Agree (A), Neutral (N), Disagree (D) and strongly disagree (SD). Recapitulation of preference data is presented in Table 3. A high percentage of strongly agree shows that the variable is very popular. These variables are service satisfaction, comfort, security, trip cost, punctuality and travel time reliability. On the other hand, the least desirable variables can be identified based on the percentage of strongly disagree. The variables that are least desirable are education, family number, income, duration of walking time, trip cost and party size of traveler.

\section{2. Data of mode choice}

There are five operating existing access modes in Juanda, namely Bus, Taxi, Travel Car, Private Car, and Motorcycle. To improve the quality of airport access trips, the Government plans a new mode, Train. This train transportation is designed to be elevated by the Gubeng Station - Waru Station - Juanda International Airport. In the questionnaire, it is asked about what modes will be chosen by the respondents if the airport train is 
assumed to have operated according to the route. This survey can obtain data from the mode selection. The selection proportion of Bus is $8,3 \%$ and the other modes consecutively are Train 35,0\%, Travel Car 5,4\%, Taxi 6,9\%, Private car 38,4\% and motorcycle $5,4 \%$.

Table 3.

Recapitulation of Airport Passenger Preference Data's.

\begin{tabular}{|l|c|c|c|c|c|c|}
\hline \multicolumn{1}{|c|}{ Variables } & Symbol & SA(\%) & A (\%) & N (\%) & D(\%) & SD (\%) \\
\hline Income & Q1 & 24,2 & 34,8 & 7,6 & 26,2 & 7,2 \\
\hline Family number & Q2 & 15,7 & 35,4 & 12,3 & 26,6 & 10,0 \\
\hline Education & Q3 & 7,2 & 12,3 & 20,8 & 45,9 & 13,8 \\
\hline Purpose of trip & Q4 & 27,2 & 33,9 & 16,9 & 18,3 & 3,7 \\
\hline Trip duration (travel time) & Q5 & 42,4 & 41,2 & 8,9 & 6,2 & 1,2 \\
\hline Number of baggage & Q6 & 29,1 & 35,6 & 12,3 & 19,7 & 3,3 \\
\hline Trip cost & Q7 & 50,1 & 27,6 & 6,3 & 11,7 & 4,3 \\
\hline Trip distance & Q8 & 32,3 & 50,4 & 6,7 & 8,1 & 2,4 \\
\hline Punctuality & Q9 & 49,1 & 37,1 & 4,9 & 7,9 & 1,0 \\
\hline Travel time reliability & Q10 & 43,1 & 36,7 & 8,8 & 9,6 & 1,9 \\
\hline Frequency & Q11 & 31,0 & 39,9 & 10,8 & 16,4 & 1,9 \\
\hline Party size of traveller & Q12 & 24,0 & 29,2 & 13,4 & 29,1 & 4,2 \\
\hline Duration of waiting time & Q13 & 30,2 & 37,2 & 13,3 & 16,4 & 2,8 \\
\hline Duration of walking time & Q14 & 18,8 & 33,6 & 15,8 & 25,4 & 6,4 \\
\hline Number of transfer & Q15 & 34,0 & 29,4 & 14,8 & 19,0 & 2,8 \\
\hline Security & Q16 & 57,0 & 33,0 & 4,3 & 5,2 & 0,4 \\
\hline Comfort & Q17 & 62,0 & 29,6 & 4,0 & 4,2 & 0,2 \\
\hline Baggage capacity & Q18 & 34,1 & 43,7 & 8,0 & 13,7 & 0,6 \\
\hline Service satisfaction & Q19 & 65,8 & 26,3 & 3,2 & 3,9 & 0,8 \\
\hline
\end{tabular}

\section{RESULTS AND DISCUSSION}

\section{1. Results of Factor Analysis}

Factor analysis is a set of processes consisting of variable selection, variable grouping and creating simpler new factors. Results of all processes will create new factor formulations that contain a group of variables. From the responses to 19 variables that are processed in factor analysis, a number of new factors can be produced which are fewer than the number of origin variables. The number of new factors and their magnitude survey presented as a whole in Table 4.

Each factor in the table above has a number of certain influences ranging from the largest to the smallest. A large amount of influence shows that these factors are very dominant to be considered in the selection of access modes by passengers. The formulation and amount of contribution from the most dominant factors in each region are as shown in Table 5. 
The number of new factors and the total contribution of all factors.

Table 4.

\begin{tabular}{|c|c|c|c|}
\hline Districts & $\begin{array}{c}\text { Number of } \\
\text { New Factors }\end{array}$ & Name of Factors & $\begin{array}{c}\text { Contribution of all } \\
\text { Factors }(\%)\end{array}$ \\
\hline Surabaya & 6 & $\begin{array}{l}\text { Transportation }\left(\mathrm{Su}_{1}\right) \text {, Social }\left(\mathrm{Su}_{2}\right) \text {, } \\
\text { Accessibility }\left(\mathrm{Su}_{3}\right) \text {, Satisfaction }\left(\mathrm{Su}_{4}\right) \text {, } \\
\text { Baggage }\left(\mathrm{Su}_{5}\right) \text {, Travelling-1 }\left(\mathrm{Su}_{6}\right)\end{array}$ & 61,88 \\
\hline Sidoarjo & 6 & $\begin{array}{l}\text { Satisfaction }\left(\mathrm{Si}_{1}\right) \text {, Transportation }\left(\mathrm{Si}_{2}\right), \\
\text { Social }\left(\mathrm{Si}_{3}\right), \text { Accessibility }\left(\mathrm{Si}_{4}\right), \text { Travelling- } \\
2(\mathrm{Si}), \text { Party size }\left(\mathrm{Si}_{6}\right)\end{array}$ & 64,08 \\
\hline Jombang & 4 & $\begin{array}{l}\text { Satisfaction }\left(\mathrm{Jo}_{1}\right) \text {, operational pattern-1 } \\
\left(\mathrm{J}_{2}\right) \text {, travelling-3 }\left(\mathrm{J}_{3}\right) \text {, total trip cost }\left(\mathrm{J}_{4}\right)\end{array}$ & 68,07 \\
\hline Gresik & 4 & $\begin{array}{l}\text { Operational pattern-2 }\left(\mathrm{Gr}_{1}\right) \text {, satisfaction } \\
\left(\mathrm{Gr}_{2}\right) \text {, operational pattern-3 }\left(\mathrm{Gr}_{3}\right) \text {, party size } \\
\text { of traveler }\left(\mathrm{Gr}_{4}\right)\end{array}$ & 70,68 \\
\hline Malang & 4 & $\begin{array}{l}\text { Operation \& convenience }\left(\mathrm{Ma}_{1}\right) \text {, } \\
\text { satisfaction }\left(\mathrm{Ma}_{2}\right) \text {, social }\left(\mathrm{Ma}_{3}\right) \text {, frequency } \\
(\mathrm{Ma} 4)\end{array}$ & 68,62 \\
\hline
\end{tabular}

The formulation of the most dominant factors.

Table 5.

\begin{tabular}{|l|l|l|c|}
\hline Districts & \multicolumn{1}{|c|}{$\begin{array}{c}\text { Most dominant } \\
\text { factors }\end{array}$} & \multicolumn{1}{|c|}{ Formulation } & $\begin{array}{c}\text { Contribution } \\
(\%)\end{array}$ \\
\hline Surabaya & Transportation $\left(\mathrm{Su}_{1}\right)$ & $\begin{array}{l}0,653 \mathrm{Q} 8+0,715 \mathrm{Q} 9+0,753 \mathrm{Q} 10+ \\
0,618 \mathrm{Q} 11\end{array}$ & 13,423 \\
\hline Sidoarjo & Satisfaction $\left(\mathrm{Si}_{1}\right)$ & $\begin{array}{l}0,839 \mathrm{Q} 16+0,838 \mathrm{Q} 17+0,671 \mathrm{Q} 18+ \\
0,801 \mathrm{Q} 19\end{array}$ & 14,678 \\
\hline Jombang & Satisfaction $\left(\mathrm{Jo}_{1}\right)$ & $\begin{array}{l}0,638 \mathrm{Q} 1+0,832 \mathrm{Q} 16+0,855 \mathrm{Q} 17+ \\
0,876 \mathrm{Q} 19\end{array}$ & 22,400 \\
\hline Gresik & Operation pattern-2 & $\begin{array}{l}0,548 \mathrm{Q} 5+0,673 \mathrm{Q} 8+0,883 \mathrm{Q} 9+ \\
0,852 \mathrm{Q} 10\end{array}$ & 22,479 \\
\hline \multirow{2}{*}{ Malang } & Opr 1$)$ & $\begin{array}{l}0,513 \mathrm{Q} 5+0,552 \mathrm{Q} 8+0,817 \mathrm{Q} 9+ \\
0,822 \mathrm{Q} 10+0,766 \mathrm{Q} 16+0,777 \mathrm{Q} 17+\end{array}$ & 26,376 \\
& convenience $(\mathrm{Ma} 1)$ & $0,514 \mathrm{Q} 18$ & \\
\hline
\end{tabular}

Factor analysis in Table 3 and Table 4 produces factors that influence modal choice in general, not yet referring to certain types of modes. To see the effect of these factors specifically per mode, it is necessary to make a mathematical model of mode choice to quantitatively determine the probability value of selection.

\section{2. Logit Model of Mode Choice Probability}

The logit model is a comparison of probability function between a certain mode and reference mode. In this analysis, the reference mode is a private vehicle. There is five models in a set of the multinomial model in a studied district. Those are the logit model for Bus, Train, Taxi, Rent Car, and Motor Cycle. As the results, the logit models of mode choice for some regions as the hinterland of JIA are as follow: 


\section{Logit models of access modes}

Tabel 6.

\begin{tabular}{|c|c|c|}
\hline $\begin{array}{c}\text { Origin } \\
\text { Districts }\end{array}$ & Modes & Logit models $(g(x))$ with private car as reference mode \\
\hline \multirow[t]{5}{*}{ Surabaya } & Bus & $-14,49-0,03 \mathrm{Su}_{1}-0,14 \mathrm{Su}_{3}+0,36 \mathrm{Su}_{4}+0,75 \mathrm{Su}_{5}+0,22 \mathrm{Su}_{6}$ \\
\hline & Train & $-6,78+0,18 \mathrm{Su}_{1}-0,10 \mathrm{Su}_{3}+0,16 \mathrm{Su}_{4}-0,11 \mathrm{Su}_{5}+0,36 \mathrm{Su}_{6}$ \\
\hline & Taxi & $-8,98+1,17 \mathrm{Su}_{1}+0,06 \mathrm{Su}_{3}+0,09 \mathrm{Su}_{4}-0,06 \mathrm{Su}_{5}+0,30 \mathrm{Su}_{6}$ \\
\hline & Travel car & $-72,36-0,41 \mathrm{Su}_{1}+4,93 \mathrm{Su}_{3}-0,76 \mathrm{Su}_{4}-0,49 \mathrm{Su}_{5}-0,75 \mathrm{Su}_{6}$ \\
\hline & Motorcycle & $0,68+0,06 \mathrm{Su}_{1}+0,03 \mathrm{Su}_{3}-0,50 \mathrm{Su}_{4}-0,38 \mathrm{Su}_{5}+0,45 \mathrm{Su}_{6}$ \\
\hline \multirow[t]{5}{*}{ Sidoarjo } & Bus & $-6,01+0,09 \mathrm{Si}_{1}+0,10 \mathrm{Si}_{2}-0,02 \mathrm{Si}_{5}+0,18 \mathrm{Si}_{6}$ \\
\hline & Train & $-5,89+0,27 \mathrm{Si}_{1}-0,01 \mathrm{Si}_{2}-0,07 \mathrm{Si}_{5}-0,02 \mathrm{Si}_{6}$ \\
\hline & Taxi & $-13,87+0,22 \mathrm{Si}_{1}+0,40 \mathrm{Si}_{2}+0,23 \mathrm{Si}_{5}-0,23 \mathrm{Si}_{6}$ \\
\hline & Travel car & $-3648,33+16,29 \mathrm{Si}_{1}-31,83 \mathrm{Si}_{2}-23,97 \mathrm{Si}_{5}+415,62 \mathrm{Si}_{6}$ \\
\hline & Motorcycle & $-4,33-0,31 \mathrm{Si}_{1}+0,34 \mathrm{Si}_{2}+0,35 \mathrm{Si}_{5}-0,40 \mathrm{Si}_{6}$ \\
\hline \multirow[t]{5}{*}{ Jombang } & Bus & $8,28-1,04 \mathrm{JO}_{3}$ \\
\hline & Train & $3,80-0,41 \mathrm{Jo} 3$ \\
\hline & Taxi & $2,27-0,49 \mathrm{Jo}_{3}$ \\
\hline & Travel car & $-3,95+0,24 \mathrm{Jo}_{3}$ \\
\hline & Motorcycle & $0,70-0,24 \mathrm{Jo}_{3}$ \\
\hline \multirow[t]{5}{*}{ Gresik } & Bus & $0,55-0,38 \mathrm{Gr}_{1}+0,15 \mathrm{Gr}_{2}+0,15 \mathrm{Gr}_{3}$ \\
\hline & Train & $-14,06-0,21 \mathrm{Gr}_{1}+0,65 \mathrm{Gr}_{2}+0,51 \mathrm{Gr}_{3}$ \\
\hline & Taxi & $-21,28+0,61 \mathrm{Gr}_{1}+0,53 \mathrm{Gr}_{2}+0,08 \mathrm{Gr}_{3}$ \\
\hline & Travel car & $-26,24-0,73 \mathrm{Gr}_{1}+0,88 \mathrm{Gr}_{2}+1,67 \mathrm{Gr}_{3}$ \\
\hline & Motorcycle & $-16,16+1,08 \mathrm{Gr}_{1}-0,28 \mathrm{Gr}_{2}-0,16 \mathrm{Gr}_{3}$ \\
\hline \multirow[t]{5}{*}{ Malang } & Bus & $0,25 \mathrm{Ma}_{2}+0,01 \mathrm{Ma}_{3}-1,46 \mathrm{Ma}_{4}$ \\
\hline & Train & $0,09 \mathrm{Ma}_{2}-0,21 \mathrm{Ma}_{3}+0,22 \mathrm{Ma}_{4}$ \\
\hline & Taxi & $154,56 \mathrm{Ma}_{2}+121,39 \mathrm{Ma}_{3}-1534,70 \mathrm{Ma}_{4}$ \\
\hline & Travel car & $-0,01 \mathrm{Ma}_{2}-0,22 \mathrm{Ma}_{3}+0,19 \mathrm{Ma}_{4}$ \\
\hline & Motorcycle & $113,25 \mathrm{Ma}_{2}+94,32 \mathrm{Ma}_{3}-1141,19 \mathrm{Ma}_{4}$ \\
\hline
\end{tabular}

Based on the Logit Model above, it can formulate the probability model of each mode. Generally, the formulation of each mode choice probability is presented in the following equation:

$$
P(\text { Bus })=\frac{e^{g(x) \text { Bus }}}{1+g(x) \text { Bus }+g(x) \text { Train }+g(x) \text { Taxi }+g(x) \text { Travel }+g(x) \text { Motorcycle }},
$$

and

$$
P(\text { Private car })=\frac{1}{1+g(x) \text { Bus }+g(x) \text { Train }+g(x) \text { Taxi }+g(x) \text { Travel }+g(x) \text { Motorcycle }} .
$$


Quantitatively, model choice probability values can be calculated based on the Mode Choice Probability Models above. Q value is the quantification of the respondent's answers. SD response has 1 value; $\mathrm{D}$ has 2 value, $\mathrm{N}$ has 3 value, $\mathrm{A}$ has 4 value and $\mathrm{SA}$ has 5 value. Factor value is obtained by substituting the variables (Q) in factor formulation. The factor value is then substituted in logit function and probability equations so that it can obtain the probability value of each mode, as in the following tables.

Table 7.

Average probability values of modes choice

\begin{tabular}{|c|c|c|c|c|c|c|}
\hline Districts & \multicolumn{7}{|c|}{ Average Probability Value of Modes } \\
\hline & Bus & Train & Taxi & Travel & Private car & Motor cycle \\
\hline Surabaya & 0,00681 & 0,02285 & 0,00587 & 0,00000 & 0,81020 & 0,15427 \\
\hline Sidoarjo & 0,04166 & 0,13231 & 0,00378 & 0,00000 & 0,79094 & 0,03131 \\
\hline Jombang & 0,34031 & 0,32756 & 0,03974 & 0,02968 & 0,20292 & 0,05980 \\
\hline Gresik & 0,30312 & 0,03694 & 0,00187 & 0,00035 & 0,65617 & 0,00155 \\
\hline Malang & 0,09996 & 0,36587 & 0,00000 & 0,13740 & 0,39677 & 0,00000 \\
\hline
\end{tabular}

Based on the choice probability values, private vehicles are still the most interest mode by air passengers in all the studied areas. This is reasonable because private vehicle modes have high flexibility compared to other modes. The priority of transportation arrangement policies in airports in the world is to encourage the use of high-occupancy vehicles such as trains and buses. The policy aims to reduce the traffic load on the highway which is an access road to the airport, minimize the environmental impact due to the density of vehicle traffic and also to save energy. Along with that, the Indonesian Government is working with the airport management company to hold bus and train transportation as an airport access mode. This policy will also be applied at JIA.

Regarding the plan to operate the airport train, passengers from Malang and Jombang areas indicate a great interest in the mode. This is due to two issues, firstly because there is already a train line to Surabaya and the second because there is a quite rapid highway to the airport. In conditions of crowded highway traffic, the use of private vehicles is uncomfortable. For passengers from Surabaya and Sidoarjo, they have low interest in both train and bus modes. It can be assumed that it is caused by a relatively close distance to the airport location. So for passengers from Surabaya and Sidoarjo, the mode of private vehicles and motorcycle become the favorite modes. Especially for passengers from Gresik, it can be seen that there is a low interest in the mode of the train because there is yet available train line. While the existing bus lines are available serving the Gresik - Airport routes. So the interest in using bus modes is relatively high compared to train mode.

Efforts to encourage the use of high-occupancy vehicles must pay attention to the factors that explicitly influence the choice of modes, as in Table 5. For example for passengers from Surabaya, the choice of train mode is strongly influenced by the transportation factor (Su1), satisfaction factor (Su4) and traveling-1 (Su6) factors. The magnitude of the influence of each factor is the exponential value of the parameter coefficient. 


\section{CONCLUSION}

Research in mapping the pattern of selection airport access mode brought the results in charateritics of access mode choice by passengers of JIA. Overall JIA currently serves 38 (thirty eight) districts in East Java province, but only 5 (five) districts are the object of analysis in this study because of the reason for the adequacy of the data in statistics. Based on passengers characteristics and origin of passengers, private car dominated for all passenger's district areas except Jombang. This is due to the distance and the availability of access mode. This domination is not applicable for passengers from Jombang that has around $89 \mathrm{~km}$ from JIA. This selection due to the mix traffic to the airport that cause longer travel time. The domination of private car for almost all JIA's passengers imply that the distribution of originating passengers cause ineffective planning of public transport to serve the passengers. The public transports, as airport access modes, should be planned in the regional corridor which has a high probability of modal choice. The high probability of mode choice shows the high interest of passengers in the mode. Therefore, spacially mapping the probability of choosing a mode in airport catchment area becomes very important. However, this may can be investigated further by having projecting the raise of the demand from each districts. If the demand from each area of study growing fast, the possibility of having specific bus route or train route, as in Soekarno Hatta Airport, can be proposed.

\section{R E F E R E N C E S}

Airport Cooperative Research Program (ACRP), 2008, Airport ground access mode choice model, ACRP Synthesis 5, Transportation Research Board, Washington D.C.

Akar, G., 2013, Ground access to airports, case study: Port Columbus International Airport, Journal of Air Transport Management, 30, 25 - 31

Alhussein, Saad N, 2011, Analysis of Ground Access Mode Choice King Khaled International Airport, Riyadh, Saudi Arabia, Journal of Transport Geography, Vol. 19, page: 1361 - 1367.

Arbues, P., Banos, J.F., Mayor, M., Suarez, P., Determinants of Ground Transport Modal Choice in Long Distance Trips in Spain, Transportation Research Part A, Vol. 84, page: 131 - 143

Bao, D, Guo, T, Hua, S, 2015, Analysis of airport passenger's access mode choice based on SP/RP combined data, Journal of Wuhan University of Technology (Transportation Science and Engineering), 39, 763-767

Chang, Y.C., 2013, Factors affecting airport mode choice for elderly air passengers, Transportation Research Part E: Logistics and Transportation Review, Vol 57, page $105-112$.

Chebli, H., Mahmassani. H. S., 2003, Air traveler stated preferences toward new airport landside access mode services, Annual Meeting of Transportation Research Board, Washington DC.

Choo, S., You, S., Lee, H., 2013, Exploring characteristics of airport access mode choice: a case study of Korea, Transportation Planning and Technology, 36, 335-351.

Furuichi, M, and Koppelman, F.S, 1994, An analysis of air traveler departure airport and destination

Gokasar, I., Gunay, G., 2017, Mode Choice Behavior Modelling of Ground Access to Airport: A Case Study in Istanbul, Turkey, Journal of Air Transport Management, Vol: 59, page: 1 - 7

Gupta, S., Vovsha, P., Donnelly, R., 2008, Air Passenger Preference for Choice of Airport and Ground Access Mode in The New York City Metropolitan Region, Transportation Research Record: Journal of The Transportation Research Board 2042, page: 3-11.

Harvey, G, 1986, Study of Airport Access Mode Choice, Journal of Transport Engineering, Vol 112 No.5, page: $525-545$. 
Jou, R.C., Henser, D.A., Hsu, T.L., 2011, Airport Ground Access Mode Choice Behaviour after The Introduction of a New Mode: a Case Study of Taoyuan International Airport in Taiwan, Transportation Research Part E: Logistic and Transportation Review 47, page: $371-381$.

Keumi, C., Murakami, H., 2012, The Role of Schedule Delays on Passengers Choice of Access Modes: A Case Study of Japan's International Hub Airports, Transportation Research Part E, Vol. 48, page: $1023-1031$.

Kropko, J., 2008, Choosing between multinomial logit and multinomial probhit models for analysis of unordered choice data, A Thesis Submitted to the Faculty of The University of North Carolina at Chapel Hill, 1 - 46.

Lee Kyu, J., Eui Yoo, K., Han Song, K., 2016, Studi on Travellers Transport Mode Choice Behavior Using The Mix Logit Model: A Case Study of The Seoul - Jeju Route, Journal of Air Transport Management, Vol. 56, page: 131 - 137

Mamdoohi, A., Saffarzade, M., Taherpour, A., Panah, M. Y., 2012, Modelling air passengers ground access mode choice: a case study of IKIA, International Journal of Modelling and Optimization, 2, 147.

Pasha, M. M., \& Hickman, M. (2016). Airport ground accessibility: review and assessment. 38th Australasian Transport Research Forum (ATRF 2016), (November), 15p. Retrieved from http://atrf.info/papers/2016/index.aspx\%0Ahttps://trid.trb.org/view/1457919

Psaraki, V., Abacoumkin, C., 2002, Access mode choice for relocated airport: the new Athens International Airport, Journal of Air Transport Management 8, page: 89 - 98.

Roh, H., J., 2013, Mode choice behavior of various airport user groups for ground airport access, The Open Transportation Journal, 7.

Tam, M.I, Lam, W.H.K, Lo, H.P., 2011, The impact of travel time reliability and perceived service quality on airport ground access mode choice, Journal of Choice Modelling 4, page: $49-69$.

Tsamboulas, D.A., Evmorfopoulos, A.P., Moraiti, P., 2012, Modelling Airport Employess Commuting Mode Choice, Journal of Air Transport Management, Vol. 18, page: 74-77 